\title{
AN INVESTIGATION OF THE EFFECTS OF COCOYAM ON LEPROSY
}

\author{
T. F. Davey, M.D., M.Sc. \\ and \\ C. Ross, M.B., Ch.B., D.T.M.
}

It has been suggestẹd by Oberdorffer that a diet rich in cocoyam may be a predisposing agent in infection with leprosy $\left({ }^{1}\right)$. The action of cocoyam in this respect is attributed to a sapotoxin which has a specific action, primarily on the adrenal glands. The suggestion is based on observations made in S.E. Nigeria where it is maintained that the greatest amount of cocoyam is eaten during the months of January to March, and during this time many neural cases of leprosy have a positive result to bacteriological tests for the lepra bacillus.

This suggestion is of considerable importance in South Eastern Nigeria, where the incidence of leprosy is very high, and coroyam is an important article of diet. The discovery of a relationship between cocoyam and leprosy would simplify the immense problem of leprosy control.

Three main varieties of cocoyam are eaten in Nigeria, namely Colocasia Antiquorum Xanthosoma Sagittifolium, and Xanthosama Mafaffia. Africans describe and name several subvarieties of these according to taste, colour, and keeping properties. Only one variety, namely X.Sagittifolium, is eaten in large quantities, and in certain parts of the Niger Delta and in the Cameroons under British Mandate it is a staple article of diet. For our purpose we are concerned with the Ibo people, a tribe several millions strong. This tribe has a strong racial susceptibility to leprosy, the incidence of which varies between Io and 150 per mille. We have never found it less than Io per mille. Among these people also, coroyam is extensively cultivated and eaten, but its culture and usage follow old established rules, reference to which will be made later. The existence of a sapotoxin in cocoyam was pointed out by Clark (2) and it will be necessary to refer repeatedly to his work.

In order to prove the truth of Oberdorffer's suggestion it would be necessary to establish two facts.

(x). The sapotoxin must be actually eaten as such. Its presence must be demonstrated in the parts of the cocoyam normally used for food, it must not be destroyed by normal methods of preparation, and if it is present only at certain seasons, those 
seasons must correspond with the times of the year when cocoyam is eaten.

(2). The sapotoxin must have a specific action on the human subject.

The study of the second of these two subjects abounds in difficulties. It would be almost impossible to subject a sufficiently large group of non-lepers to the degree of control and observation required over a sufficient period of time in order to obtain conclusive results. On the other hand, if the sapotoxin has a specific predisposing action, it should also have a deleterious action on people already suffering from leprosy, part.cularly people whose resistance to the disease is low. The suggestion was indeed based in the first place on the observation of cases of leprosy. This paper reports the results of feeding

Settiement with excess of cocoyam. Children were chosen as their resistance to leprosy is notoriously low. Many of them were unsatisfactory cases from the standpoint of successful treatment, many were at puberty and thus the best soil was provided for demonstrating any deleterious effect of sapotoxin.

Twenty-e the main types of leprosy (Group I). An equal number of controls was also chosen (Group 2), comparable in age, type and extent of the disease with those of Group I. All the children in both groups were subjected to detailed observation from one cocoyam season to the next, and their progress was followed throughout the year until the cycle was completed.

From March Ist 1940 when the experiment was commenced, until June 3oth I940, the children in Group I in addition to their normal diet were given massive doses of cocoya $m$ daily, the average daily amo

this time the children concerned consumed no less than $2 \mathrm{cwt}$. of prepared cocoyam each. We were forced to stop the supply at the end of June as the cocoyam season is then over, and the tubers are almost unobtainable. Throughout this period no leprosy treatment whatever was given, the children in both groups were examined daily, weights were recorded weekly, the sedimentation test was carried out fortnightly and thorough bacteriological tests were carried out at least monthly. A record was also kept of everything the children ate apart from the cocoyam provided. No cor:oyam was given to the children in Group 2, but records of diet and medical observation and tests were carried out as for Group I. These were continued in both groups until March Ist I94I. A detailed record was thus obtained of the progress of the children 
in both Groups over a period of one year, the only difference between the groups being thai those in Group I received massive doses of cocoyam for four months of the year.

The results of the test are presented in Table $\mathrm{I}$.

\section{TABLE I}

GROUP I (Cocoyam given).

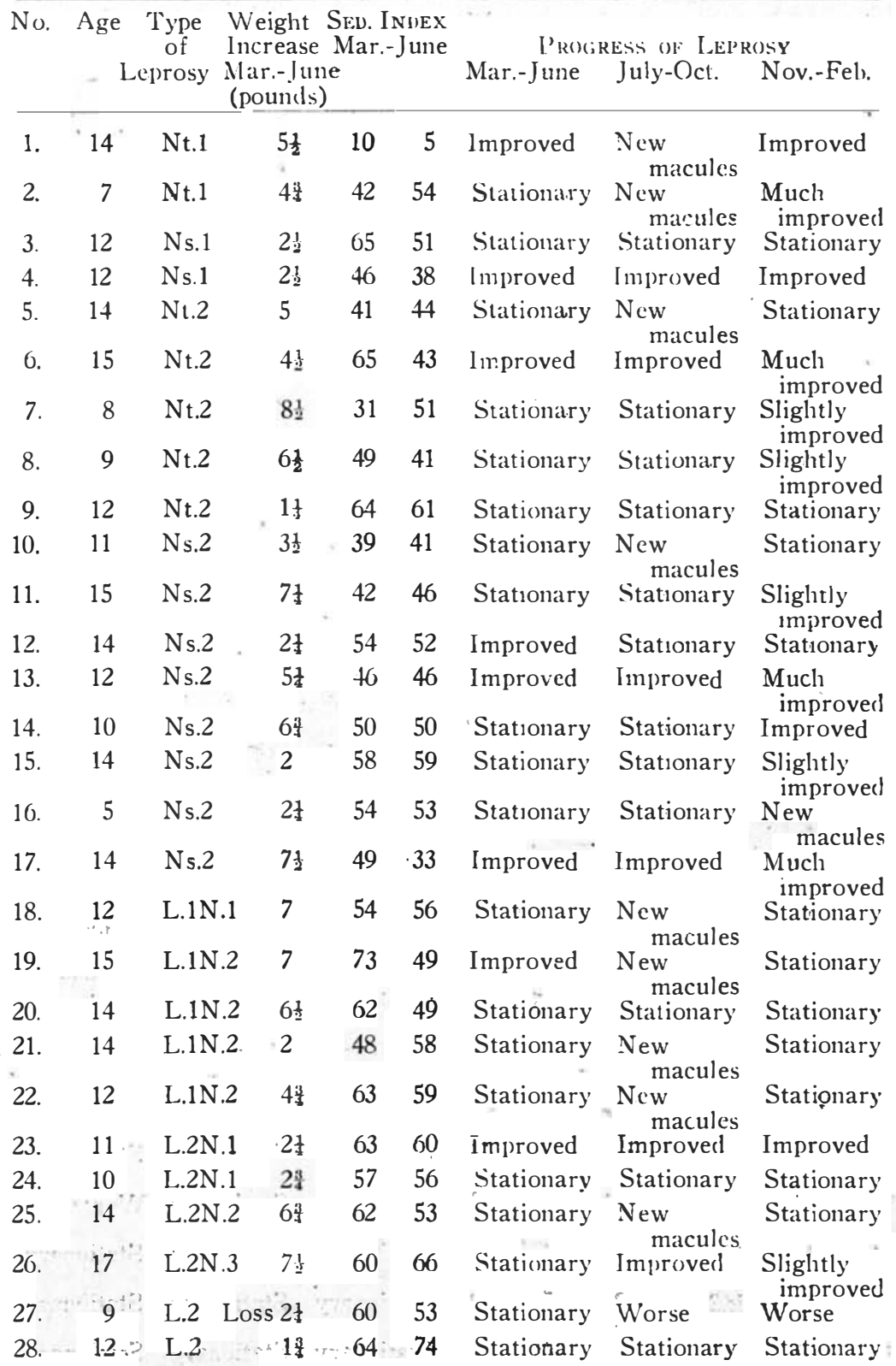


GROUP 2 (No cocoyam given).

No. Age Type Weight Sed. Invex of Increase Mar.-June Leprosy Mar.-June

Progress of Leprosy

Mar.-June July-Oct. Nov.-Feb. (pounds)

\begin{tabular}{|c|c|c|c|c|c|c|c|c|}
\hline 29. & 13 & Nt.1 & $4 \frac{1}{2}$ & 39 & 32 & $\begin{array}{l}\text { Slightly } \\
\text { improved }\end{array}$ & Improved & Improved \\
\hline 30. & 0 & Nt.1 & $3 \frac{1}{2}$. & 40 & 62 & Stationary & Stationary & Stationary \\
\hline 31. & 4 & Ns.1 Loss & $1 \frac{1}{2}$ & 33 & 1 & Stationary & & \\
\hline 32. & 11 & Ns.l & 47 & 44 & 40 & New & $\begin{array}{l}\text { ed } \\
\text { ry }\end{array}$ & $\operatorname{Impr}$ \\
\hline 33. & 12 & Ns.2 & $1 \frac{1}{2}$ & 34 & 40 & Improved & Improved & Improved \\
\hline 4. & 15 & Nt.2 Loss & 27 & 60 & 69 & Stationary & Worse & Worse \\
\hline 35. & 9 & Nt.2 & 4 & 56 & 57 & Stationary & $\underset{\text { macules }}{\mathrm{New}}$ & Stationa \\
\hline 36. & 8 & Ns.2 & 3 & 61 & 62 & $\begin{array}{l}\text { Slightly } \\
\text { improved }\end{array}$ & Stationary & Stationary \\
\hline 37. & 15 & Nt.3 & $2 !$ & 31 & 31 & ( & Stationary & $\begin{array}{l}\mathrm{New} \\
\text { maculcs }\end{array}$ \\
\hline 38. & 11 & Ns.2 Loss & 11 & 38 & 29 & $\underset{\text { macules }}{\mathrm{New}}$ & Stationary & Stationary \\
\hline 39. & 14 & Ns.2 & 51 & 57 & 39 & $\begin{array}{l}\mathrm{New} \\
\text { macules }\end{array}$ & Stationary & Away \\
\hline 40. & 13 & Ns.2 Loss & & 50 & 44 & Improved & $\begin{array}{l}\text { New } \\
\text { macules }\end{array}$ & Stationary \\
\hline 41. & 11 & Ns.2 Loss & $3 t$ & 60 & 62 & nary & $\mathrm{New}$ & Improved \\
\hline 42. & 9 & Ns.2 & $\frac{1}{2}$ & 39 & 40 & $\begin{array}{l}\text { Slightly } \\
\text { improved }\end{array}$ & $\begin{array}{l}\text { New } \\
\text { macules }\end{array}$ & Improved \\
\hline 43. & 12 & Ns.2 & 4 & 45 & 42 & Improved & Improved & Improved \\
\hline 44. & 5 & Ns.2 & 13 & 37 & 42 & oved & $\begin{array}{l}\text { Slightly } \\
\text { improved }\end{array}$ & ved \\
\hline 45. & 15 & Ns.2 Loss & & 18 & 69 & $y$ & $\begin{array}{l}\text { New } \\
\text { macules }\end{array}$ & $\operatorname{Imp}$ \\
\hline 40. & 13 & L. 1 N. 3 & 3 & 64 & 58 & Stationary & $\begin{array}{l}\text { New } \\
\text { macules }\end{array}$ & Stationary \\
\hline 47. & 9 & L.I.N.1 Ls & s1? & 58. & 37 & Stationary & Statıonary & $\begin{array}{l}\text { New } \\
\text { macules }\end{array}$ \\
\hline 48. & 12 & L.1.N.2 Ls & s1 & 65 & 64 & Imoroye & Stationary & $\begin{array}{l}\text { New } \\
\text { macules }\end{array}$ \\
\hline 49. & 11 & L.1N.1 & $3 \frac{1}{2}$ & 65 & 68 & $y$ & $\begin{array}{l}\text { New } \\
\text { macules }\end{array}$ & ry \\
\hline 50. & 14 & L.1N.2 & 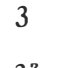 & 61 & 55 & $y$ & $\begin{array}{l}\text { New } \\
\text { macules }\end{array}$ & $\operatorname{Im}$ \\
\hline 51. & .11 & L.2. Loss & $3 \frac{3}{5}$ & 45 & 58 & Worse & Stationary & \\
\hline 52. & 10 & L. $2 \mathrm{~N} 1$ & nil & 41 & 44 & Stationary & Stationary & Stationary \\
\hline 53. & 14 & L. $.2 \mathrm{~N} .1$ & 87 & 58 & 63 & Stationary & Stationary & Worse \\
\hline 54. & 15 . & L. 2 & $3 t$ & 47 & 34 & Stationary & Stationary & Stationary \\
\hline 55. & $8 \ldots$ & L. 2 & 2 & 56 & 59 & Stationar & Stat & Stationary \\
\hline 56 & 15. & L.2 & & 41 & 39 & Stationary & Stationary & Station \\
\hline
\end{tabular}


The Cairo classification of leprosy is used, the Sedimentation Index is recorded as obtained in March and June, and the periodic progress of leprosy as based on clinical appearances and bacteriological findings is indicated. The general high level of the Sedimentation Index gives a clue to the unsatisfactory type of case chosen for the test, so that every possible opportunity was given for the toxic effects of the sapotoxin to evidence themselves.

It is clear that children in Group I suffered from no ill effects from the cocoyam provided, their progress indeed comparing favourably with that of Group 2, the children of which were given no cocoyam.

\section{I)ISCUSSION.}

There are several possible fallacies in this experiment and it is necessary to deal with these singly.

1. The type of cocoyam used.

The variety of cocoyam used in the test is known by the Ibo name of Nkasi, and is the only type used throughout S.E. Nigeria to any large extent. It is a variety of Xanthosoma Sagittifolinm.

\section{The method of preparation.}

There are only two methods of preparation in common use. (a) The cocoyam is boiled and then pounded in a mortar, when it is called fufu. This is the usual method and was used by us in the test. (b) When a hurried meal is required, the cocoyam may be thrust into the fire and roasted.

In his experiments with animals, Clark used raw cocoyam and it may be suggested that the sapotoxin is heat liable and the metr nd of preparation we adopted destroyed the sapotoxin, thus producing negative results.

If the sapotoxin is unstable to heat, it can immediately be stated that its importance is negligible, for we have questioned 400 Africans as to their methods of preparing and eating cocoyam and not one single individual stated that he ever ate cocoyam in the uncooked state. When describing toxic symptoms in human beings Clark apparently assumes that the tubers were eaten in the usual African way, namely after cooking. It is of interest to note that ciery one of the children of Group I ate per week far more cocoyam than that consumed by the case of fatal poisoning recorded by Clark.

There remains one possible way in which improperly cooked cocoyam may actually find its way into the diet. It was acknowledged that a careless person, in particular a child, may occasionally remove a roasted cocoyam from the fire before it i properly 
cooked, but it was also pointed out that the uncooked tubers have an unpleasant taste.

3. Seasonal Variation in Sapotoxin Content.

According to Clark, the toxicity of 'cocoyam in Nigeria is maximal in December and minimal in February. In South Eastern Nigeria the amount of cocoyam eaten in December is small, so that for practical purposes this observation loses much of its importance. The season during which cocoyam is eaten follows a settled routine and bears a definite relationship to another foodplant, namely the yam (Dioscorea). Yams are everywhere esteemed as the finest food. It is interesting to note-that among the Ibos, yams are a man's crop, planted and tended almost exclusively by men. The culture of the rather despised cocoyam is relegated to women, and cocoyam is valued as food only when yams are scarce. The corms of cocoyam are planted from May onwards, and the harvest begins in December. Very little cocoyam is eaten in December however because the yam harvest is still at its zenith, and yams are preferred. Yams remain plentiful until the end of February, when the yam planting season begins. From this time yams become increasingly scarce and expensive and it is then that the cocoyam comes into its own. From April until June it is a staple article of diet. These facts are well illustrated in Table 2 which shows the prices of cocoyam and yam throughout the year at Umuahia market, one of the most important markets in the area. Figures are given for both I939 and I940.

\section{TABLE 2}

Prich in PFNCE Plik CWr.

\begin{tabular}{lcccccccccccc}
\hline 1939 & Jan. & Feb. & Mar. & Apr. & May & June & \multicolumn{1}{c}{ July } & \multicolumn{1}{c}{ Ang. Sept. Oct. Nov. Dec. } \\
Yam & 14 & 14 & 28 & 29 & 35 & 37 & 24 & 18 & 9 & 20 & $12 \frac{1}{2}$ & 16 \\
Yoco & & 7 & $8 \frac{1}{2}$ & 14 & 12 & 11 & 10 & 11 & unobtainable & \\
yam & & & & & & & & & $\ldots$ & & & \\
1940 & & & & & & & & & & & \\
Yam & 22 & 31 & 31 & 44 & 56 & 37 & 36 & 21 & 23 & 19 & 20 & 26 \\
$\begin{array}{l}\text { Coco } \\
\text { yam }\end{array}$ & $8 \frac{1}{2}$ & $8 \frac{1}{2}$ & 17 & 17 & 21 & 22 & unobtainable & & & \\
\hline
\end{tabular}

The most important feature of this table is that from September until December in each year, cocoyams were unobtainable, and it may be taken for granted that the amount eaten in December is negligible. Undue attention should not be paid to the fact that yams are consistently dearer than cocoyams. It should be borne in mind that throughout the area fully 90 per cent of the nopulation are small farmers, all growing yams, and yams are only 
offered for sale in the market when in excess of a man's requirements. As the demand is usually in excess of the supply, they command a good price, but even though cocoyams are cheaper yams remain the more important article of food until the planting season begins.

Oberdorffer states that the greatest amount of cocoyam is eaten between January and March. We are unable to agree with this statement and our opinion is approved by every African we have questioned. Although cocoyam is certainly eaten during the months of January to March, far more is eaten from April onwards when yams are scarce. It was for this reason that we selected the months of March to June for our experiment.

Seasonal variation in the appearances of leprosy.

During the months of June, July and August, both yams and cucoyams are scarce, any that are obtainable being of inferior quality. The yam harvest commences towards the end of August when yams again become plentiful. In former times the months of June, July and early August were a definite famine period, maize being the only available crop. The introduction of cassava, itself a toxic food, relieved the situation, but even to-day Africans acknowledge that diet is unsatisfactory during this period. To a rural population living at poverty level, an increase in the price of staple foods means that less money can be spent on meat, fish and other luxuries, and for many people the diet is both poor and unbalanced during the months concerned. It also happens that this period follows that in which most cocoyam is eaten. During the same months the rainy season reaches its height, mosquitoes and in consequence, malaria, are prevalent, while respiratory affections are common, and there seems little doubt that there is a general lowering of resistance to infection at this time. It follows that from June to mid August conditions are provided annually which are favourable to infection with leprosy, the visible signs of which should appear in succeeding months. It is interesting to notice that 26 of the 56 children observed exhibited either lepra reaction or new macules during the year of observation, and these appeared as follows:

Mar. April May June July Aug. Sept. Oct. Nov. Dec. Jan. Fel, 2 nil nil $3 \begin{array}{lllllll}2 & 5 & 4 & 6 & 3 & 2 & 1 \\ \text { nil }\end{array}$

There were II cases in Group I, I5 in Group 2, while two of the children had fresh crops of macules in both March and October.

These findings are of interest when compared with those of 
lowe $\left({ }^{3}\right)$ but we do not attach any importance to them as it will be necessary to observe a far larger group before any conclusion of value can be reached.

\section{Diet of the children observed.}

If we had intended to carry out a test under true laboratory conditions, it would have been necessary to provide all the children with a controlled diet, those in Group 2 having no cocoyam whatever. This was not our intention. The results of tests maje on laboratory animals living in unnatural conditions and fed on an artificial diet may prove fallacious when applied to human beings. The ill effects of the sapotoxin in cocoyam are of small account unless they are exerted under actual living conditions. The purpose of our test was to provide such conditions in the case of Group 2, and grossly exaggerate them as far as cocoyam was concerned in the case of Group I. We therefore did not attempt the impossible task of rigidly controlling the diet of the children in Group 2. Any such attempt would indeed have vitiated the test. For part of the period of the test, yams are unobtainable, and the only alternatives in real life to the average African are cocoyams and cassava. Cassava is itself a toxic food, and a diet consisting entirely of cassava would have produced toxic effects similar to those of cocoyam. We therefore contented ourselves with keeping as accurate a record as possible of the diet of all the children, leaving them to their own devices as far as actual meals were concerned. It was inevitable that a varying amount of cocoyam found its ways into the diet. The amount varied from one child to another, several of them eating very small amounts and living mainly on cassava, but after reviewing the progress of the children in relation to their diets, we cannot trace any relationship between the amount of cocoyam eaten and the progress of leprosy observed by us during the period of the test.

\section{The sapotoxin.}

Clark states that the sapotoxin is a glucoside, the toxic effects of which are directly mainly to the kidneys, adrenals and liver. Symptoms are produced when cocoyam is eaten in large quantities over a period, and include lethargy, albuminuria and abdominal distention. These effects are counteracted by foods containing cholesterol, cystine, or sulphur in organic combination, e.g., animal protein, meat, fish, game, etc., palm oil, yeast. The diet of Ibos, particularly of the poorer classes is deficient in animal protein, but includes palm oil and yeast, the latter being coniained in palm wine, the universal beverage. There is no doubt that fresh 
palm wine counteracts the toxic effects of cassava which resemble those attributed to cocoyam. The diet of all the children included a certain amount of these foods.

Although we do not consider the results of our te mately conclusive, we can state that after providing and exaggerating those conditions of life favourable to the exhibition of specific toxic effects by the sapotoxin of cocoyam, we could not trace any deleterious effects on leprosy for which it could have been responsible.

South Eastern Nigeria presents to-day a sorry picture to the leprologist, for almost every known agent predisposing to infection with leprosy is in operation. A dense population, but recently brought into contact with civilisation, overcrowding, ignorance, primitive sanitary conditions, poverty, an unbalanced diet, diseases such as yaws, malaria, helminth infections, anaemia, all these factors are not only present, but almost universal, anu it is small wonder that their combined effects produce an incidence of leprosy almost unparalleled in the world. It is possible that the sapotoxin of cocoyam also plays its part, but its action is not specific, and it is but one among a host of factors, many of which are obvious and remediable.

Our thanks are due to the Agricultural Officer, Umuahia, who provided us with the data presented in Table 2, and the hindreds of Africans who supplied us with information.

\section{SUMMARY.}

I. In order to investigate the action of the sapotoxin of coroyam on leprosy, and thereby estimate its importance as a predisposing agent in infection with leprosy, a group of children suffering from leprosy were fed with massive doses of cscoyam. Cases with low resistance were selected in order to provide conditions most suitable for the exhibition of the toxic effects of the sapotoxin. The children, together with an equal number of controls, were subjected to detailed observation for one year.

2. No deleterious effects whatever could be observed.

3. Possible fallacies are dealt with and a wider discussion un questions of diet and seasonal variations of appearances of leprosy leads to the conclusion that although the sapotoxin may possibly exert some slight toxic effect in actual living condition, this action is not specific and the sapotoxin is but one among many factors predisposing to infection with leprosy in Nigeria.

(1). Oberdocrffer, N. J. An investigation into the predisposing ractors of leprosy in Soutl Nigeria. Arch f. Schiff-u. Tropen-Hug. 42 (1938), 367-372. 
(2) Clark, A. A report on the effects of certain poisons contained in foodplants of West Africa upon the health of the native races. Jour. Trop. Hed \& Hyg, 39 (1930), 285-295.

(3). Lowe, J., and (hatterji, S. N. Seasonal variations in leprosy in Calcutta. Internat. Jour. of Leprosy, 7 (1939). 137-148.

IIt is regretted that war conditions have considerably delayegd the publication of this article.-The Authors.] 